\title{
Marcin Lisiecki
}

marlis@umk.pl

Wydział Politologii i Studiów Międzynarodowych

Uniwersytet Mikołaja Kopernika w Toruniu

\section{KULTUROWY WYMIAR POLSKIEJ ORIENTALISTYKI. WIESŁAW KOTAŃSKI I JEGO BADANIA NAD KULTURĄ JAPONII}

\section{The cultural dimension of Polish oriental studies. Wiesław Kotański and his research on Japanese culture}

\author{
君ならで \\ 誰にか見せむ \\ 梅の花 \\ 色をも香をも \\ 知る人ぞ知る \\ 紀友則 \\ Jeśli nie ciebie, \\ to kogoż mam obdarzyć \\ tym kwieciem śliwy? \\ Wszak na jej woni, barwie \\ pozna się tylko znawca!
}

Ki-no Tomonori

Streszczenie: Głównym celem artykułu jest analiza dorobku Wiesława Kotańskiego w kontekście światowych badań kultury Japonii. Możemy wskazać co najmniej dwie przyczyny podjęcia tego tematu. Po pierwsze, był on jednym z najważniejszych badaczy Japonii w Polsce. Zasłynął nie tylko pracami na rzecz utworzenia polskich studiów japonistycznych, lecz także próbami sformułowania metodologii badań japońskiej kultury. Ponadto, jako thumacz przybliżał polskim czytelnikom zabytki japońskiej literatury. Po drugie, jako jeden z niewielu współczesnych polskich orientalistów jest uznawany za ważnego badacza Japonii poza granicami Polski. Szczególnie istotny jest jego wkład w tłumaczenie najstarszego zabytku piśmiennictwa japońskiego, czyli Kojiki, w tym także wypracowanie metod przekładu tego niezwykle trudnego i wieloznacznego tekstu. 
Slowa kluczowe: Wiesław Kotański; Japonia; japonistyka; kultura; Kojiki; intonacja; przekład.

\begin{abstract}
The main aim of the article is to analysis the achievements of Wiesław Kotański in the context of global research on Japanese culture. We can identify at least two reasons for taking up this subject. Firstly, he was one of the most important researchers of Japan in Poland. He is not only renowned for his works for the creation of Polish Japanese studies, but also with attempts to formulate a methodology for the study of Japanese culture. In addition, as a translator, he brought the monuments of Japanese literature closer to the Polish readers. Secondly, as one of the few contemporary Polish orientalists, he is considered to be an important researcher of Japan outside Poland. His contribution to the translation of the oldest monument of Japanese literature, Kojiki, is particularly important. This includes the development of methods for translating this extremely difficult and ambiguous text.
\end{abstract}

Key words: Wiesław Kotański; Japan; Japan Studies; culture; Kojiki; intonation; translation.

\title{
Wprowadzenie
}

Znaczenie Wiesława Kotańskiego (1915-2005) dla polskich badań nad kulturą Japonii wydaje się bezsprzeczne'. Świadczyć o tym mogą zwieńczone sukcesem działania na rzecz powstania w Polsce japonistyki na Uniwersytecie Warszawskim w 1955 roku (patrz: Kotański, Seyfried 1961: 153; Bednarczyk 2014: 53), a także prowadzone przez niego badania nad kulturą i religiami starożytnej Japonii, językiem japońskim oraz aktywność translatorska przybliżająca polskim czytelnikom japońską literaturę. Jednakże próbując określić miejsce Kotańskiego w międzynarodowej nauce, postawić musimy kilka pytań dotyczących jakości jego dorobku, jak i polskiej orientalistyki. Wynikają one z refleksji nad wartością i znaczeniem polskiej nauki i sprowadzają się do wątpliwości: czy polskie badania

${ }^{1} \mathrm{Z}$ tego powodu, że informacje dotyczące życia i pracy badawczej Wiesława Kotańskiego są dość dobrze opracowane, odsyłamy do następujących prac polskich orientalistów: A. Żuławska-Umeda (2012), E. Pałasz-Rutkowska (2005), Y. Matsui (2006), J. M. Künstler (2005). 
Kulturowy wymiar polskiej orientalistyki...

nad kulturami Azji mogą być oryginalne i wnieść coś nowego do gmachu nauki światowej, czy też skazani jesteśmy na marginalizację i epigonizm. Łatwiej zrozumiemy te zastrzeżenia, kiedy dostrzeżemy - oczywiście nie umniejszając ich znaczenia - że wkład polskich orientalistów do nauki sprowadza się w dużym stopniu do przełożenia zabytków literatury azjatyckiej, traktatów filozoficznych lub dzieł współczesnej literatury na język polski, wykorzystując funkcjonujące już tropy interpretacyjne i założenia metodologiczne. Warto dodać, że w kontraście do tradycji europejskich badań orientalistycznych, dysponujemy jedynie wybranymi przykładami przekładów, z języków oryginalnych, dzieł literackich. Zresztą liczba tłumaczeń azjatyckiej literatury na język polski, zarówno współczesnej, jak i klasyki (a może przede wszystkim niej) nie pretendują nawet do stopnia satysfakcjonującego ${ }^{2}$. Ponadto zastanówmy się, czy w polskiej orientalistyce wskazać możemy, ograniczając się do Azji Wschodniej i Południowo-Wschodniej, na badaczy takiej rangi, jak np.: William G. Aston (18411911), Basil Hall Chamberlain (1850-1935), Fiodor Szczerbatski (Федор И. Щербатской, 1866-1942), Marcel Granet (1884-1940), Edward Conze (1904-1979), Heinrich R. Zimmer (1890-1943), Nelly Naumann (1922-2000) czy chociażby Donald L. Keene (1922-2019)?

Odpowiadając na postawione wyżej pytania, uwzględnić musimy kilka ważnych faktów. Zainteresowanie sprawami Wschodu wynikało najczęściej z relacji politycznych i kontaktów handlowych z mieszkańcami Bliskiego Wschodu, a nie dalszej części Azji. Wskazuje na to polska badaczka Indii Helena Willman-Grabowska twierdząc, że: „Wschodem dla dawnej Polski była tatarszczyzna i turecczyzna. Wynikało to z naszych warunków geograficznych i politycznych, stało się też podłożem dla przyszłych studiów orientalistycznych w tym kierunku. O dalszym Wschodzie było głucho" (Willman-Grabowska 1957: 237). Kontakty te, skądinąd ważne i interesujące, przyczyniły się do dość wąskiego ujęcia badań orientalistycznych i nie dostrzegania w polityce i kulturze Indii, Chin, Japonii czy Korei problemów badawczych (patrz: Chmielewski, Reychman 1966; Willman-Grabowska 1957). Co więcej, do dziś w orientalistyce (nie tylko polskiej) nie została wypracowana ani definicja przedmiotu badań, ani spójna metodologia i narzędzia badawcze. W rezultacie polskie prace

${ }^{2}$ Dla porównania, i pomijając przekłady na język angielski lub niemiecki, warto wskazać na znaczną liczbę wydań tłumaczeń w języku rosyjskim. Przykładem jest chociażby seria Памятники письменности Востока (Pomniki piśmiennictwa Wschodu) wydawana od roku 1959. 
orientalistyczne poświecone są w dużej mierze językoznawstwu i literaturoznawstwu, a w mniejszym stopniu filozofii, historii czy badaniom antropologicznym (patrz: Dziekan 2014: 5; Lisiecki 2018: 626). Jednakże nie powinno umniejszać to znaczenia badań polskich orientalistów, gdyż wśród nich możemy bez większego trudu wskazać osoby, które zaznaczyły się wyjątkowymi pracami oraz pozycjami w światowej nauce. Wymienić należy chociażby na takich badaczy, jak: Andrzej Gawroński (1885-1926), Stanisław Schayer (1889-1941), Eugeniusz Słuszkiewicz (1901-1981), Witold Jabłoński (1901-1957) czy Janusz Chmielewski (1916-1998)³. Nadmienić należy, że wymienieni orientaliści odznaczyli się nie tylko przekładami literatury Indii czy Chin, lecz także znaczącymi pracami - również w wymiarze międzynarodowym - z zakresu językoznawstwa, buddologii, filozofii i logiki, wypracowanych w tych kręgach kulturowych.

Zanim podejmiemy się zadania opisania i analizy pozycji Wiesława Kotańskiego w polskiej i światowej orientalistyce, warto powtórzyć postawione wyżej pytania o oryginalność polskich badań. Podkreślić należy, że zadaniem jakie sobie stawiamy, nie jest apologetyczne ujęcie jego dorobku, a próba krytycznej analizy. W tym celu przyjrzyjmy się historii polskiej japonistyki, jako odrębnemu działowi orientalistyki, a następnie określimy znaczenie Kotańskiego dla jej rozwoju. Drugim punktem będzie określenie specyfiki jego prac, czyli głównych tematów, metodologii, a także wkładu do światowych badań nad kulturą Japonii. Podkreślając znaczenie tego punktu dodać należy, że był on aktywnym autorem prac poświęconych językowi, literaturze, religiom oraz sztuce, jak również tłumaczem zabytków literatury starojapońskiej i współczesnej.

\section{Obecność Wiesława Kotańskiego w polskiej japonistyce}

Historia polskiej japonistyki jest stosunkowo krótka, gdyż sięga drugiej połowy wieku XX i związana jest z Uniwersytetem Warszawskim (patrz: Kotański 2000; Okazaki 2000; Bednarczyk 2014), będąc, obok koreanistyki, najmłodszą gałęzią badań orientalistycznych w Polsce.

3 Oprócz wymienionych wyżej badaczy wskazać również możemy na inne osoby, które w znacznym stopniu zaznaczyły się w badaniach społeczności azjatyckich, lecz nie są oni uznawani za orientalistów, jak: Bronisław Piłsudski (1866-1918), Wacław Sieroszewski (1858-1945), Benedykt Dybowski (1833-1930), Maria A. Czaplicka (1886-1912), Wanda Dynowska (1888-1971) oraz Maurycy Frydman (1901-1977). 
Kulturowy wymiar polskiej orientalistyki...

I wreszcie historia ta nierozerwalnie związana jest z osobą Wiesława Kotańskiego. Zresztą opinia ta jest wielokrotnie powtarzana nie tylko przez autorów zajmujących się tym tematem, lecz także przez samego Kotańskiego (patrz: Kotański 1961: 153; Bednarczyk 2014: 54; Pałasz-Rutkowska 2005: 190; Künstler 2005: 87). Interesujące są zwłaszcza opinie samego Kotańskiego, albowiem świadczyć one mogą nie tyle o świadomości jego pozycji i wkładu w rozwój studiów nad Japonią, lecz przede wszystkim o trudnościach, jakie towarzyszyły początkowemu okresowi polskiej japonistyki. Możemy się domyślać, że oprócz drobnych informacji dotyczących kultury i polityki Japonii w ówczesnym czasie, nauczanie skupiało się przede wszystkim na poznaniu języka tego kraju. Ponadto powolne rozszerzanie zainteresowań uwarunkowane było również tym, że brakowało wówczas książek w języku japońskim oraz naukowych opracowań, a sami japoniści byli przez całe lata pozbawieni możliwości wyjazdu do Japonii (Bednarczyk 2014: 53-54). Przyznać także należy, że w tym okresie niemalże każdy badacz zajmujący się tym tematem i, co niezwykle ważne, dysponujący znajomością języka japońskiego, wywierał znaczący wpływ na polskie studia japonistyczne ${ }^{4}$. Zaś ograniczone możliwości docierania do tekstów źródłowych oraz prowadzenia badań terenowych owocowały powolnym pojawianiem się problemów badawczych, które pozwalałyby na pełniejsze dotarcie do specyfiki i zawiłości japońskiej kultury, a przede wszystkim na zaistnienie na płaszczyźnie międzynarodowej. W rezultacie tychże działań powołane zostały, oprócz wspomnianej warszawskiej japonistyki, trzy jednostki uniwersyteckie prowadzące kursy poświęcone badaniom Japonii: Zakład Japonistyki i Sinologii na Uniwersytecie Jagiellońskim, Zakład Japonistyki na Uniwersytecie im. Adama Mickiewicza w Poznaniu oraz Katedra Japonistyki na Uniwersytecie Mikołaja Kopernika w Toruniu (patrz: Okazaki 2000; Okazaki 2012; Majewicz 2012, Łukasiewicz 2000; Stefański 2000). Ponadto środowisko japonistyczne wydawało w latach 1993-2003 czasopismo naukowe „Japonica”, „Silva Iaponicarum”, które funkcjonuje nieprzerwanie od roku 2004, zaś od 2011 roku „Analecta Nipponica. Journal of Polish Association for Japanese Studies"s. Świadczyć to może o tym,

4 Ważnymi osobami, które oprócz Kotańskiego wywarły wpływ na kształt polskich badań japonistycznych są: zajmująca się historią Japonii Jolanta Tubielewicz (1931-2003) oraz badacz i thumacz literatury japońskiej Mikołaj Melanowicza (1935- ).

5 Na Uniwersytecie Mikołaja Kopernika w Toruniu wychodziło także, z przerwami, w latach 1998-2014 czasopismo „Japonica Toruniensia”. 
że japonistyka w Polsce stała się samodzielną i rozwijającą się dziedziną badań orientalistycznych.

We wstępie do artykułu zaznaczyliśmy, że naszym celem nie jest apologetyka, lecz krytyczne ujęcie działalności Wiesława Kotańskiego na polu badań japonistycznych. W zamierzeniu tym kryją się dwie przyczyny. Po pierwsze, winniśmy przedstawić myśli polskiego orientalisty w możliwie najbardziej rzetelny sposób, uwzględniając przy tym współczesny stan badań nad kulturą Japonii. Po drugie, analizując jego prace i koncepcje, możemy się odnieść do badań japonistycznych w szerokim kontekście i określić zawarte w nich tendencje oraz metodologię badawczą. Na początku wieku XXI, na kilka lat przed śmiercią Kotańskiego, w specjalnym numerze „Tygodnika Powszechnego", zamieszczono jego odpowiedź na pytanie: dlaczego poświęcił całe życie badaniu kultury japońskiej. Udzielił on interesującej, choć skądinąd typowej dla orientalistów, odpowiedzi, mianowicie:

Doskonale potrafię sobie wyobrazić życie człowieka, który jakiś okres czasu przeznacza np. na kulturę chińską, potem przerzuci się na tybetańską, z kolei na mongolską itd. To może być interesujące, ale wymaga też pewnych predyspozycji, którymi nie dysponuję. Oczywiste też jest, że predyspozycje charakterystyczne dla mojej psychiki nie są równe predyspozycjom człowieka, który lubi stosunkowo częste zmiany. W moim przeświadczeniu takie częste zmiany nie prowadzą do dogłębnego zbadania tematu, choć do określonych celów mogą być przydatne (Kotański 2000).

Typowość tejże odpowiedzi polega na tym, że oczywistym zdaje się zgłębianie przedmiotu badań, uzupełnianie, korygowanie analiz oraz poszukiwanie nowych sposobów dotarcia do istoty danej kultury. Ponadto odnosi się ona do określenia tego, co to znaczy być specjalistą. Zwłaszcza w kontekście badań kultur azjatyckich, gdzie niezbędne jest - oprócz samej wiedzy o strukturach, instytucjach, mitach, rytuałach czy sposobach porządkowania rzeczywistości - dysponowanie znajomością języka, jakim posługują się przedstawiciele analizowanej społeczności ${ }^{6}$. Warto zatrzymać

${ }^{6}$ Warto dodać, że do pełniejszego (może zadawalającego) zbadania i zrozumienia, np. Indii nie wystarczy znajomość języka angielskiego, hindi czy, jeśli chodzi o dawną literaturę, sanskrytu, lecz wskazane jest posługiwanie się kilkunastoma spośród kilkudziesięciu innych języków, jakimi posługują się mieszkańcy tego kraju. Podobna sytuacja występuję w Chinach, gdzie mieszkańcy posługują się kilkudziesięcioma odmiennymi dialektami. Również w Japonii zaobserwować możemy funkcjonowanie, oprócz grupy języków riukiuańskich, wielu odmian języka japońskiego. 
się chwilę i przyjrzeć się uważnej tym wątkom. W pierwszym przypadku możemy wyrazić zasadne zastrzeżenie, czy rzetelny badacz nie powinien uwzględniać różnych metodologii, czy komparatystycznego ujęcia, albowiem może to pozwolić na pełniejsze zrozumienie zachowań i aktywności intelektualnej ludzi reprezentujących daną kulturę. W przypadku drugiej kwestii znacznie trudniej jest jednoznacznie orzec, kim może być specjalista. Czy to ten, kto posiada wiedzę i posługuje się wyraźnie sprecyzowaną metodologią i narzędziami umożliwiającymi przeprowadzenie badań, czy też ten, kto reprezentuje daną dziedzinę badawczą, np. japonistykę? Musimy mieć na uwadze to, że każda ze skrajności zdaje się powodować niekorzystne dla nauki zamknięcie. Albowiem ogólne ujęcie powodować może nierozumienie szczegółów, zaś rezultatem skupiania uwagi na szczegółach, może być niedostrzeżenie sensu całości ${ }^{7}$.

W trakcie trwania przeszło 50. letniej pracy naukowej polski orientalista zostawił po sobie kilkadziesiąt artykułów i kilkanaście książek, w których podejmował się analizy japońskiej kultury, a także próbował sformułować teorię badań nad kulturą . Jednakże trudno o wykazanie spójnej drogi oraz założeń, jakie poczynił odnośnie tego tematu. Głównie z tego względu, że wielokrotnie korygował i zmieniał swoje założenia, co zresztą niejednokrotnie podkreślał (patrz: Kotański 1990: 21; Żuławska-Umeda 2006: 34). Dlatego też postaram się o wykazanie, moim zdaniem, najważniejszych punktów i ukazanie, jakie znaczenie posiadały one dla międzynarodowych badań nad kulturą japońską. Warto podkreślić, że był on jednym z niewielu badaczy Azji, który w swoich pracach przedstawił zarys metodologii oraz opisał narzędzia badawcze. I tak pojęcie „kultury” rozumiał on jako rozmaite typy zachowań i rezultaty zachowań ludzi (Kotański 1977: 92), zdając sobie sprawę ze złożoności tego pojęcia oraz różnorodności ujęć, metod i narzędzi badawczych. Do tego dodawał, że każdą dziedzinę kultury można nazywać techniką, techniką osiągania pewnych celów czy wyników, zajmowania się określonymi obiektami, wykonywania pewnych ruchów, przejawiania myśli itp. (Kotański 1977: 93). Postulował on szerokie

7 Jako komentarz do tego sporu przytoczyć możemy fraszkę Tadeusza Kotarbińskiego (1957:13):

Do jasnych dążąc głębin - nie mógł trafić w sedno

Śledź pewien, obdarzony naturą wybredną.

Dokądkolwiek wędrował, zawsze nadaremno:

Tu jasno, ale płytko - tam głębia, lecz ciemno.

${ }^{8}$ Spis prac Kotańskiego od roku 1950 do 2005 sporządził Yoshikazu Mitsui (patrz: Mitsui 2012: 7-14). 
rozumienie „kultury”, którą pojmował jako sposób działania, zarówno na poziomie intelektualnego zrozumienia czy „oswojenia” rzeczywistości, jak i czynności, których zwieńczeniem będą wytwory materialne. W konsekwencji skutkować to miało znalezieniem takich narzędzi badawczych, które powinny w sposób maksymalnie efektywny umożliwić dotarcie do szerokiego spektrum wymiarów kultury. Dodatkowo podkreślał on zmienność kultury i to, że należy ją traktować rozwojowo, gdyż jedne jej przejawy przemijają, inne zaś rodzą się i dochodzą do szczytów rozkwitu, by z czasem również ulec całkowitemu lub częściowemu zapomnieniu (Kotański 1977: 92). I chociaż jest to zjawisko naturalne, to znacząco utrudnia badania. W kontekście badań orientalistycznych, co warto dodać, podejście Kotańskiego było (i nadal jest) wyróżniające, gdyż wciąż wyraźną jest tendencja to tworzenia takiego modelu kultury, który ma opierać się próbom jej destabilizacji czy rozmycia.

Metodologia badań kultury japońskiej była jednym z ważniejszych tematów, jakim Kotański poświęcił uwagę, którą stale modyfikował i uzupełniał. Główne założenia teorii i narzędzi badawczych, a także podstaw teoretycznych wyśledzić możemy w wielu jego tekstach na przestrzeni kilkudziesięciu lat. Poświęćmy im chwilę uwagi, również z tego względu, że pretendować ona miała, z powodu jej ogólności, nie tylko do dogłębnego poznania Japonii, lecz także innych kultur. Warto dodać, że odwołania do pracy innych badaczy, w kontekście badań nad kulturą, umieszczał on w swoich tekstach niezbyt często i trudno o precyzyjne wykazanie źródeł, nawiązań i inspiracji. Niemniej jednak nie jest to niemożliwe i z pewną dozą prawdopodobieństwa możemy sądzić, że są to prace Alfreda Korzybskiego, Tadao Umesao, Josefa Kreinera, Ronalda Barthesa, Umberto Eco i innych semiologów, także ze Szkoły Moskiewsko-Tartuskiej (patrz: Kotański 1995a; Badnarczyk 2014b: 46)9. Specyfika ujęcia Kotańskiego polegała na tym, że rozumiał on pojęcie „kultury” w konfrontacji z pojęciem „cywilizacji”, które charakteryzować się miały rozwojem, działaniem i racjonalnym odniesieniem się do rzeczywistości ${ }^{10}$. Ów funkcjonalny model kultury (lub cywilizacji) opierał się na rozróżnieniu, we wczesnym okresie jego aktywności naukowej, czterech odrębnych typach działania ludzi wobec środowiska naturalnego i jego przekształcania,

9 W pracach Kotańskiego odnaleźć też możemy odniesienia do fenomenologii Romana Ingardena, hermeneutyki Hansa-Georga Gadamera, a także prakseologii Tadeusza Wójcika. Oczywiście nie jest to lista zamknięta i możliwe, a nawet wskazane jest jej uzupełnienie.

${ }^{10}$ Kotański czasem rozróżniał te pojęcia, a niekiedy używał je jako synonimy. 
organizacji społecznych oraz symbolicznej komunikacji. W kolejności są to: biotechnika, demotechnika, hilotechnika i semiotechnika. Z kolei w późniejszym okresie uzupełnił on swoje rozważania teoretyczne o mizohologię i jamatologię, które odnosić się miały tylko do kultury Japonii.

W pierwszej kolejności wskazał on na biotechnikę, którą rozumiał jako dziedzinę działań skierowanych na utrzymanie optymalnej dla człowieka kondycji wszystkich żywych bytów w środowisku opanowanym przez dane społeczeństwo (Kotański 1995a: 27). Sprowadza się ona do wszelkiej aktywności ludzkiej, opartej na celowym działaniu zmierzającym do opanowania i wykorzystywania środowiska naturalnego oraz jego bogactwa dla utrzymywania życia. Ponadto do tego typu działań, oprócz hodowli zwierząt czy uprawy roślin, zaliczyć musimy wszelkie techniki zmierzając do zachowania zdrowia i poprawnej psychofizycznej kondycji człowieka (Kotański 1995a: 28). Druga, czyli demotechnika, rozumiana jest jako opis tej sfery aktywności człowieka, która sprowadza się do koordynacji dążeń całej społeczności i skutku takich zabiegów, do dystrybucji rozmaitych dóbr materialnych i duchowych między członków społeczności (Kotański 1995a: 28). Innymi słowy, dotyczy ona tych działań, które prowadzą do legitymizowania i reprodukowania instytucji społecznych i politycznych. Hilotechnika, czyli trzeci typ, wiąże się z takimi działania człowieka, w wyniku których przekształca on materię nieżywioną w pełnowartościowe, potrzebne ludziom produkty (towary, obiekty), dzięki czemu zmienia się ich dawna wartość użytkowa na nową (Kotański 1995a: 29). W ich rezultacie pojawiają się nie tylko przedmioty i obiekty ułatwiające egzystencję ludzką, lecz także takie, które służyć mają do celów społecznych i religijnych. Jako przykłady wskazuje on chociażby na wodociągi, elektrownie, a także budowę świątyń i sprzętu liturgicznego (Kotański 1995a: 29). Ostatni typ, czyli semiotechnika, określana jako domena aktywności ludzkiej, skierowana jest na tworzenie postrzegalnych znaków, sygnałów itp., które na mocy konwencji lub ze względu na jakieś podobieństwo nawiązują do określonych wydarzeń czy obiektów, będących składnikami rzeczywistości i uznawanych w danym społeczeństwie (Kotański 1995a: 30). Oprócz tekstów, rytuałów i innych działań społecznych, w ramach semiotechniki, badać można wszelkie przejawy aktywności artystycznej, naukowej oraz zabawy. Podkreślić należy, że funkcjonalny model zachowań ludzkich opisany przez Kotańskiego zakłada, oprócz pozytywnych aspektów działalności ludzkiej (zarówno na poziomie indywidualnym i zbiorowym), umożliwiającej trwanie i rozwój, także aktywność destrukcyjną, o której nie wolno zapominać, 
gdyż odgrywa ona istotną rolę w zachowaniach ludzkich. Przykładami takich praktyk, które rozpatrywać można w ramach badań nad kulturą, mogą być np. alkoholizm, narkomania, niszczenie obiektów religijnych (lub politycznych), a także zużywanie nieodnawialnych zasobów naturalnych czy zanieczyszczanie środowiska.

Uwzględnienie mizuhologii i jamatologii, jak zaznaczyliśmy wcześniej, dotyczyło tylko i wyłącznie Japonii. Wprowadzając to rozróżnienie Kotańskiemu chodziło o to, aby zwrócić uwagę na dwie kwestie: po pierwsze, każdy z ważnych okresów w dziejach Japonii odznaczał się swoją specyfiką i dlatego należy dokonać ich rozróżnienia, a po wtóre, dzięki temu możliwe być powinno określenie istoty japońskiej kultury oraz wyznaczenie tego, gdzie i jak jej szukać. Zależało mu przede wszystkim na wyróżnieniu w dziejach dawnej Japonii okresu poprzedzającego wpływy kultury chińskiej od tego, kiedy mieliby charakteryzować się odrębnością i niezależnością kulturową. Temu celowi służyć miało posługiwanie się pochodzącymi z Kojiki (古事記) określeniami na Japonię, czyli: mizuho (瑞穂) i jamato (大和, yamato) (patrz: Kotański 1995a: 34). W takim rozumieniu mizuhologia ograniczałaby się do najstarszej fazy w dziejach Japonii, poprzedzającej wpływy chińskie. Zaś jamatologia do okresu między IV a XVI wiekiem, czyli wyraźnych wpływów zewnętrznych wzorów kulturowych. Podkreślić należy, że Kotański wpisywał się tym w dość powszechną tendencję w badaniach nad japońską kulturą poszukiwania jej źródeł. W takim rozumieniu badania mizuhologiczne miały zmierzać do poznania systemu pierwotnych, tj. rodzimych japońskich wierzeń i praktyk religijnych, które najlepiej odzwierciedlać miały postawy Japończyków wobec środowiska, w którym żyli i działali (Kotański 1995a: 35). Ważnym dla zrozumienia propozycji badania japońskiej kultury polskiego japonisty jest uwzględnienie tego, że odwoływał się on do natywistycznych koncepcji japońskich badawczy. Mianowicie, powołując się na niemieckiego japonistę Josefa Kreinera, postulował on podążanie drogą wyznaczoną przez Motooriego Norinagę (1730-1801), który jako pierwszy wskazał potrzebę badania zabytków literatury starojapońskiej, zwłaszcza Kojiki oraz Yanagitę Kunio (1875-1962) uznawanego za twórcę japońskiej folklorystyki (patrz: Kotański 1995a: 19; Kreiner 1984: 42). Innymi słowy poszukując źródeł japońskiej kultury powinniśmy, zdaniem tych badaczy, większą atencję okazać tekstowi Kojiki oraz shintoizmowi ${ }^{11}$.

${ }_{11} \mathrm{Z}$ tego powodu, że temat ten wykracza poza ramy niniejszego artykułu musimy go pominąć. Warto jednak zaznaczyć, że wymaga on krytycznego ujęcia. 
Kulturowy wymiar polskiej orientalistyki...

\section{Kojiki i jej miejsce w badaniach Wiesława Kotańskiego nad kulturą Japonii}

Amerykański japonista Torquil Duthie, opiniując najnowszy przekład Kojiki na język angielski dokonany przez Gustava Heldta, napisał, że jest on pierwszą osobą, która zadała sobie trud przetłumaczenia imion japońskich bóstw na język angielski (Held 2014: XXIV i okładka). Przytaczając te słowa chcemy zwrócić uwagę na niezwykle istotny fakt ograniczeń wśród badaczy nie tylko dla badań nad japońską kulturą, lecz także samej nauki. $\mathrm{W}$ tym przypadku mamy do czynienia z niezbyt dokładnym rozeznaniem się amerykańskich japonistów w dyskusjach i publikacjach dotyczących przekładu i analiz Kojiki ${ }^{12}$. Z dużą dozą prawdopodobieństwa możemy przyjąć, że z powodu braku znajomości języka polskiego, co jeszcze nie jest błędem, nie byli oni w stanie zaznajomić się z przekładem Kotańskiego. Jednakże nieumieszczenie go w spisie badaczy Japonii oraz nieznajomość jego prac poświęconych przekładom japońskiego tekstu funkcjonujących w międzynarodowym dyskursie od lat 80 . XX, uznać należy za wyraźną niekompetencję, a wręcz ignorancję ${ }^{13}$. Tym bardziej, że jest on obecny w badaniach, zarówno zachodnich, jak i japońskich, jako ważny i ceniony badacz kultury Japonii. Co więcej, jeśli mielibyśmy wskazać jeden temat, dzięki któremu Kotański dokonał istotnego wkładu do badań światowych na kulturą Japonii, to jest nim Kojiki i jego przekład. Poświadczeniem tych słów może być chociażby to, że doczekał się on tłumaczeń prac na język japoński, które są szeroko komentowane wśród badaczy Japonii (patrz: Mitsui, 2006; Kotański 2004).

Pomijając wieloaspektowość prac translatoryjnych japońskiego tekstu - warto przypomnieć, że Kojiki jest najstarszym zabytkiem piśmiennictwa japońskiego ${ }^{14} \mathrm{i}$ od około XVIII wieku do pierwszej połowy

12 Dodać należy, że Kojiki od czasu pierwszego przekładu w roku 1882 przez Léona de Rosny'ego było thumaczone kilkadziesiąt razy (patrz: Hirafuji 2014 [25]: 84-86). Co więcej, przekłady tego tekstu nie funkcjonują w próżni, lecz są szeroko dyskutowane i komentowane. Zaś sami tłumacze nie są w środowisku badań nad Japonią anonimowi i znane są ich dokonania translatorskie.

13 Dla porównania wskażmy bibliografię zawartą w najnowszym niemieckim thumaczeniu Kojiki, dokonanym przez niemieckiego japonistę Klausa Antoniego, gdzie nazwisko Kotańskiego występuje (patrz: Antoni 2012: 794).

14 Powstanie Kojiki datuje się na rok 712, zaś autorem (lub raczej tym, który tylko spisał) jest Ō-no Yasumaro (太安万侶, ?-723). 
XX wieku uznawany był za wyjątkowy, a wręcz sakralny ${ }^{15}$ - skupmy uwagę jedynie na tych wątkach, które świadczyć mogą o jego znaczącej pozycji w międzynarodowych badaniach japonistycznych. W pierwszej kolejności warto wskazać na sam sposób podejścia do treści Kojiki. Mianowicie Kotański, co wyróżnia go na tle innych tłumaczy, starał się oddać piękno japońskiego tekstu i piękno japońskiej poezji w nim zawartej ${ }^{16}$. Pisał on, zakładając intencje autora Kojiki, że nie chciano aby brakowało w niej walorów estetycznych, np. pewnych akcentów poetyckich, epickiej poetyczności, itp. (Kotański 1994: 25). Rozumieć przez to winniśmy, że starając się wiernie oddać nie tylko znaczenie japońskich słów, sens wypowiedzi oraz samą poetykę tekstu wykroczył poza typowy przekład filologiczny.

Drugim istotnym wątkiem, również związanym z przekładem, jest przekroczenie granicy wyznaczonej przez natywistyczne tradycje japońskich filologów, a zwłaszcza wspomnianego wcześniej Motooriego Norinagę o konieczności zachowania „ducha języka” (言霊, kotodama). W tym przypadku chodzi o to, że uznaje się, nie tylko wśród teologów shintoistycznych, że w poszczególnych wyrażeniach japońskiego języka bytuje w pewien sposób istota, której zadaniem jest realizować treść czy intencję tego wyrażenia (Kotański 1995b: 44). Stosowanie ich w tekście, jak podkreśla Kotański, nie było jedynie chwytem literackim, lecz zapewne miało pierwotnie znaczenie magiczne, co można przyjąć za jeden z przejawów tabu wyrazowego, mającego chronić nosiciela epitetu przed jakimiś następstwami (Kotański 1995c: 39). Oznacza to, że niektórym wyrazom zawartym w Kojiki, zgodnie z założeniem „ducha języka”, przypisuje się magiczne znaczenie poprzez związek słowa z rzeczą (Sugiyama 2015: 32, Antoni b.d.; Antoni 2012: 434-437). Tymi wyrazami mają być przede wszystkim nazwy własne bóstw, które powinno się pozostawiać $\mathrm{w}$ oryginalnym brzmieniu, albowiem tłumaczenie ich na inne języki prowadzić może do naruszenia świętości. Trud oraz nowatorstwo nierzadko krytykowane o naruszanie sfery sacrum przez tradycyjnych japońskich badaczy- włożone przez Kotańskiego w przekład Kojiki polegały na tym, że traktował imiona nie tylko jako nazwy własne, lecz jako zawierające sens i otwierające nowe obszary do analizy tekstu oraz japońskich

15 Uwaga to odnosi się do tego, że tekst Kojiki uznawany jest za świętą księgę shintoizmu, co nie jest zgodne z prawdą, gdyż jego pozycja została wykreowana w okresie Meiji (1868-1912) i służyć miał legitymizowaniu władzy cesarskiej.

16 Sam zwracał uwagę na poezje kayō (patrz: Kotański 1994: 23; Żuławska-Umeda 2012: 129). 
Kulturowy wymiar polskiej orientalistyki...

mitów, a także sposobów porządkowania rzeczywistości przez ówczesnych Japończyków. Możemy to dostrzec na kilku przykładach: Amaterasu Ōmikami (天照大神) - ,Wielki i Święty Duch Świecący na Niebie”, Izanami-no mikoto (伊邪那美命) - „Duch Wzburzający Szlachetne Łono” Iznagi-no mikoto (伊邪那岐命) - „Duch Uśmierzający Szlachetne Łono", a legendarny cesarz Jimmu (神武天皇, Jinmu-tennō), czyli Yamato Kamu yamaho iwarebikoto-no mikoto (神倭伊波礼琵古命) - „Boski Młodzian Którego Urzekło Yamato".

Poszukując źródeł pierwotnej kultury japońskiej Kotański zwrócił uwagę na tekst Kojiki zarówno jako badacz, jak i tłumacz. Pozostawił on po sobie przekład tego dzieła, które na tle innych tłumaczeń wyróżnia się oddaniem specyfiki oryginału, sposobami przekładu oraz uzupełnieniu tekstu o komentarz wyjaśniający jego treść. Z wątkiem tym związane jest nie tylko doszukiwanie się treści ukrytych w imionach bóstw, lecz także (a może przede wszystkim) sposoby tłumaczenia japońskiego tekstu. Związane jest to z tym, że Kojiki napisane zostało w niezwykle specyficzny sposób, który w znaczącym stopniu utrudnia dotarcie do oryginalnych sensów. Mianowicie, do zapisu Kojiki zastosowano znaki chińskie, lecz dostosowane do języka japońskiego, co czyni ten tekst trudny do przeczytania również dla samych Japończyków. Kotański wielokrotnie podkreślał to $\mathrm{w}$ trakcie poszukiwań odpowiedniego sposobu na wierne (jeżeli jest to w ogóle możliwe) oddanie tekstu Kojiki. Remedium na tego typu trudności miało być uwzględnienie intonacji, która miała umożliwiać dotarcie do oryginalnego słowa (patrz: Kotański 1995d; Żuławska-Umeda 2006 [18]: 35). Nie wikłając się w zawiłości tego zagadnienia podkreślmy jedynie fakt, że wkład Kotańskiego do światowych badań nad Kojiki polega przede wszystkim na wyznaczeniu nowej drogi w analizie i przekładzie japońskiego dzieła ${ }^{17}$. Dodać należy, że do zwrócenia uwagi na znaczenie intonacji w próbach dotarcia do oryginalnego sensów słów zapisanych w Kojiki inspirował się on odkryciami innego tłumacza, Donlda L. Philippiego, a także japońskich językoznawców, jak: Shichirō Murayama (Żuławska-Umeda 2012 [18]: 35; Kotański 1995e: 157).

${ }^{17}$ Czytelnika zainteresowanego przykładami zastosowania intonacji w odszyfrowywaniu tekstu Kojiki odsyłamy do artykułów Kotańskiego (patrz: Kotański 1985; Kotański 1994; Kotański 1995e; Kotański 2013a; Kotański 2013b). 
Na zakończenie

Truizmem jest konstatacja, że Wiesław Kotański wywarł znaczący wpływ na polskie badania nad kulturą Japonii. Opinie te bez większego trudu, jak pamiętamy, można odnaleźć w polskiej publicystyce oraz wspomnieniach jego uczniów i współpracowników. Jednakże celem niniejszego artykułu nie było apologetyczne powtórzenie znanych już opinii, lecz krytyczne przedstawienie analizy jego dorobku. Zależało mi na wskazaniu na te prace i tematy, które uznane zostały jako istotny wkład do badań japonistycznych i dzięki którym zaznaczył on swoją obecność w przestrzeni międzynarodowej. Okazuje się, że wśród wielu wątków i pytań, które zajmowały polskiego badacza i którym dawał wyraz w swoich książkach i artykułach, możemy wyróżnić co najmniej dwa tematy, mogące świadczyć o jego znaczeniu międzynarodowym. Sprowadzały się one, po pierwsze, do określenia metod badawczych kultury Japonii, a po drugie, do analizy oraz przekładu najstarszego zabytku literatury japońskiej, czyli Kojiki. Warto przypomnieć, że poświęcenie uwagi metodologii w badaniach orientalistycznych było (i nadal jest) niezbyt często podejmowanym tematem. I to nie tylko w Polsce, lecz również w światowych badaniach, przyczyniając się tym samym do wątpliwości i stawiania pytań o specyfikę orientalistyki i jej odmienność od językoznawstwa, literaturoznawstwa, religioznawstwa czy antropologii.

Kończąc artykuł warto wspomnieć o jednej z cech Kotańskiego, która uosabiała się w dużym stopniu w trakcie rozmów, wykładów czy wystąpień naukowych. Mianowicie był on osobą przyznającą się do inspiracji naukowych, a także często wspominał o postępach w swoich badaniach, wskazując przy tym na „ślepe zaułki”, jakie napotkał w trakcie własnej drogi naukowej. W tym kontekście interesująca jest ostania rozmowa, jaką odbył 22 stycznia 2005 roku z Agnieszką Żuławską-Umedą, czytamy w niej:

Chcę tutaj wyraźnie powiedzieć, że całą wiedzę o intonacji i metodę jej wykorzystania dali mi Japończycy. To jest ich własne bogactwo naukowe, a jednak oni sami nie chcą go stosować do 'dekodowania' Kojiki. (...) Jest ona dogmatem, którego nawet naukowcy nie chcą naruszyć. Księga ta - raz zinterpretowana przez Motoori Norinagę, do dzisiejszego dnia jest dla nich nienaruszalna. Na tamtej interpretacji jeszcze ciągle opiera się wiara Japończyków, ich postawa etyczna i wzory zachowan. $Z$ naukowego punktu widzenia jest to pewna tragedia. Czasem boję się nawet, że pan Matsui [Yoshikazu Mitsui - M. L.], z powodu gorliwości, 
Kulturowy wymiar polskiej orientalistyki...

jaką wykazał tłumacząc moje artykuły, może zostać potępiony przez japońskich religioznawców (Żuławska-Umeda 2012: 36).

Warto zwrócić uwagę na ostatnie zdanie, w którym wskazuje na trudności towarzyszące badaniom tekstu Kojiki wynikające nie tylko ze specyfiki języka, lecz także utrzymującego się wciąż natywizmu w japońskiej nauce i, co ważne, powielanego również na Zachodzie. A mając w pamięci rozważania i analizy przeprowadzone przez Kotańskiego możemy tylko podkreślić, że oprócz obecności jego badań w międzynarodowych eksploracjach japonistycznych, wypracowane przez niego metody są kontynuowane, uzupełniane oraz krytykowane przez badaczy Japonii.

\section{BIBLIOGRAFIA}

Antoni, K. (b.d.). Kotodama to "Kojiki" - shinwa, reishō jujutsu, seidjiteki ideorogī to shite no kotodama. Pozyskano z: http://www2.kokugakuin. ac.jp/shukyobunka/IACM/Antoni-jp.pdf.

Antoni, K. (2012). Kojiki - Aufzeichnung alter begebenheiten. Berlin: Insel Verlag.

Bednarczyk, A. (2014a). O stanie i kierunkach rozwoju polskiej japonistyki zarys problematyki. W: A. Bednarczyk, M. Leśniczak, W: J. Nowak (red.), Verba et imagines Iaponiae. Księga dedykowana pamięci Profesora Romana S. Ingardena (1920-2011). Nowe trendy i kierunki badań w polskiej japonistyce w 5. Rocznice powołania studiów na Uniwersytecie Mikołaja Kopernika w Toruniu. Toruń: Wydawnictwo UMK.

Bednarczyk, A. (2014b). Japonologa-japonistyka-japonoznawstwo. Z historii polskiej nazwy nauki o Japonii. W: A. Bednarczyk, M. Leśniczak, W: J. Nowak (red.), Verba et imagines Iaponiae. Księga dedykowana pamięci Profesora Romana S. Ingardena (1920-2011). Nowe trendy i kierunki badań w polskiej japonistyce w 5. Rocznice powołania studiów na Uniwersytecie Mikołaja Kopernika w Toruniu. Toruń: Wydawnictwo UMK.

Chmielewski, J. (1977). Orientalistyka tradycyjna i nietradycyjna. W: Nowe specjalności w nauce współczesnej. Materiały z posiedzeń Konwersatorium Naukoznawczego Polskiej Akademii Nauk. Wrocław: Ossolineum.

Chmielewski, J., Reychman, J. (1966). Witold Jabłoński (1901-57) i warszawski ośrodek sinologiczny. W: J. Reychman. Szkice z dziejów polskiej orientalistyki (T. 2). Warszawa: PWN. 
Dziekan, M. (2014). Orientalistyka między „tradycyjną” filologią a potrzebami współczesności. W poszukiwaniu metodologii orientalistyki. Przeglad Orientalistyczny, l(2).

Heldt, G. (2014). The Kojiki. An Account of Ancient Matters. New York: Columbia University Press.

Hirafuji, K. (2014[25]). Gaikokujin ga mita Kōjiki. 130 nen toshime no Kōjiki. Kokugakuindaigaku kenkyū kaihatsu suishin kikō kiyō, 5.

Huszcza, R. (2012). Japonistyka jagiellońska - studia uniwersyteckie i ich naukowe fundamenty. W: B. Kubiak Ho-Chi (red.). Japonia w Polsce. W 90. rocznice nawiązania stosunków oficjalnych między polska i Japonia. Warszawa: Wydawnictwo UW.

Kotański, W. (1977). Kultura japońska a religia. W: J. Keller (red.). Kultura a religia. Warszawa: Iskry.

Kotański, W. (1985). Generic Denotations Accompanying Names of Gods and Men in the Kojiki. Rocznik Orientalistyczny, XLV (1).

Kotański, W. (1990). Opowieści o pierwszych władcach japońskich. Warszawa: Iskry.

Kotański, W. (1994). Poezja japońskich bogów, czyli na tropie zaczątków satyry (1). Japonica. Czasopismo poświęcone cywilizacji japońskiej, 3.

Kotański, W. (1995a). Od ekologii do mizuhologii. W: W. Kotański. W kręgu shintoizmu. Przeszłość i jej tajemnice (T. 1). Warszawa: Dialog.

Kotański, W. (1995b). „Shintō” jako tło kultury japońskiej. W: W. Kotański. W kregu shintoizmu. Przeszłość i jej tajemnice (T. 1). Warszawa: Dialog.

Kotański, W. (1995c). Dziedzictwo japońskich bogów. Uranokracja. Wrocław-Warszawa-Kraków: Zakład Narodowy im. Ossolińskich.

Kotański, W. (1995d). Intonacja jako narzędzie badań nad tekstem staro japońskim. Japonica. Czasopismo poświęcone cywilizacji japońskiej, 5.

Kotański, W. (1995e). Imiona bogów w Kojiki. W: W. Kotański. W kręgu shintoizmu. Przeszłość i jej tajemnice (T. 1). Warszawa: Dialog.

Kotański, W. (2000). Moja Japonia. Tygodnik Powszechny. Pozyskano z: http:// www.tygodnik.com.pl/japonia/kotanski.html.

Kotański, W. (2000). Wspomnienia z początków japonistyki w Polsce i inne refleksje. Japonica. Czasopismo poświęcone cywilizacji japońskiej, 12.

Kotański, W. (2004). Kojiki no atarashī kaidoku - Kotansuki no Kojiki kenkyū to gaikokugoyaku Kojiki. Y. Mitsui (hen.). Tōkyō: kinseisha.

Kotański, W. (2013a). Subete wa konton kara hajimaru - Vuiesuwafu Kotansuki-cho "Nihon no kamigami no isan" iyaku sono 1. Analecta Nipponica. Journal of Polish Association for Japanese Studies, 3. 
Kulturowy wymiar polskiej orientalistyki...

Kotański, W. (2013b). „Kojiki” no genbun o kenkyū suru riyū hōhō hōfu. Analecta Nipponica. Journal of Polish Association for Japanese Studies, 3.

Kotański, W., Seffried, K. (1961). Stosunki kulturalne między Polską i Japonią (zarys). Przeglad Orientalistyczny, 2(38).

Kotarbiński, T. (1957). Wesole smutki, Warszawa: PWN.

Kreiner, J. (1984). A Concrete Holistic Approach to the Study of Japanese Culture: An Example of Civilization Studies. Senri Ethnological Studies, 16.

Künstler, J. M. (2005). Wiesław Roman Kotański (1915-2005). Rocznik Towarzystwa Naukowego Warszawskiego, 68.

Lisiecki, M. (2018). Languages and understanding of different cultures. Remarks on the margins of a paper by Stanisław Schayer. W: М.Ф. Альбедиль, H.A. Янчевская (ред.). Mitrasampradānam. Сборник научных статей к 75-летию Ярослава Владимировича Василькова. Санкт-Петербург: Российская академия наук Музей антропологии и этнографии им. Петра Великого (Кунсткамера).

Łukasiewicz, M. (2000). Studia japonistyczne na Uniwersytecie Jagiellońskim w Krakowie. Japonica. Czasopismo poświęcone cywilizacji japońskiej, 12. Majewicz, F.A. (2012). 25 lat studiów japonistycznych w Uniwersytecie im. Adama Mickiewicza w Poznaniu. W: B. Kubiak Ho-Chi (red.). Japonia w Polsce. W 90. Rocznicę nawiazania stosunków oficjalnych między polska i Japonia. Warszawa: Wydawnictwo UW.

Matsui, Y. (2006). Wiesuwafu Roman Kotansuki keireiki. W: Y. Matsui. Ko Kotansuki hakase kinen. Chūō shokoku no nihonkenkyūte nihongo kyōiku. Tōkyo: Kiseisha.

Okazaki, K. (2000). Warszawska japonistyka - teraźniejszość i perspektywy. Japonica. Czasopismo poświęcone cywilizacji japońskiej, 12.

Okazaki, T. (2012). 90 lat historii japonistyki na Uniwersytecie Warszawskim. W: B. Kubiak Ho-Chi (red.). Japonia w Polsce. W 90. Rocznice nawiazania stosunków oficjalnych między polską i Japonia. Warszawa: Wydawnictwo UW.

Pałasz-Rutkowska, E. (2005). Profesor Wiesław Kotański (1915-2005) wybitny uczony, japonista, wychowawca pokoleń. Azja-Pacyfik, 8.

Reychamn, J. (1966). Z dziejów orientalizmu polskiego w dobie oświecenia. W: J. Reychman. Szkice z dziejów polskiej orientalistyki (T. 2). Warszawa: PWN.

Stefański, K. (2012). Uniwersytet Mikołaja Kopernika, Pracowania Języka i Kultury Japońskiej. W: B. Kubiak Ho-Chi (red.). Japonia w Polsce. W 90. Rocznicę nawiązania stosunków oficjalnych między polską i Japonią. Warszawa: Wydawnictwo UW. 
Sugiyama, Ch. (2015). „Kotoda ma” to wa nani ka? Jiburianime „sentochihironokamikakushi" o kiten to spite. PLUS $i, 11$.

Willman-Grabowska, H. (1957). Indianistyka w Polsce i studia jej pokrewne. W: S. Strelcyn (red.), Szkice z dziejów polskiej orientalistyki (T. 1). Warszawa: PWN.

Żuławska-Umeda, A. (2006 [18]). Niepokorny myśliciel - wspomnienie o Profesorze Wiesławie Kotańskim. W: Y. Matsui. Ko Kotansuki hakase kinen. Chūō shokoku no nihonkenkyūte nihongo kyōiku. Tōkyo: Kiseisha.

Żuławska-Umeda, A. (2012). Przypomnieć ostatnie badania Profesora Wiesława Kotańskiego nad poetyką japońską. W: B. Kubiak Ho-Chi (red.). Japonia w Polsce. W 90. Rocznicę nawiązania stosunków oficjalnych między polska i Japoniq. Warszawa: Wydawnictwo UW. 